\title{
Movimentos Sociais e Sistema Político nas Teorias dos Movimentos Sociais ${ }^{1}$
}

Euzeneia Carlos*

\section{Resumo}

Neste artigo, a análise das teorias dos movimentos sociais e de suas abordagens da relação do movimento com o sistema político busca demonstrar que as perspectivas dualistas, autônomas e dicotômicas das esferas da sociedade civil e do Estado precisam ser complementadas por um enfoque dinâmico desses domínios como campos em interação, continuamente coconstituídos e de fronteiras fluidas e imprecisas. Essa articulação analítica entre sociedade civil e Estado é fundamental à compreensão das interconectividades e imbricações entre atores coletivos e instituições políticas, especialmente em contextos democráticos de institucionalização dos canais de mediação. Defende-se, ainda, que a complexidade e heterogeneidade dos movimentos contemporâneos tornam falaciosas as caracterizações dos atores como formações puras, coerentes e estáveis, sendo necessário o reconhecimento das dimensões tanto culturais quanto institucionais da ação coletiva, implicadas nas interações entre os atores societários e estatais.

\section{Palavras-chave}

Movimentos sociais. Sistema político. Interações socioestatais.

\section{Abstract}

This article analysis social moviment theories, as well their approaches to the relations between social movements and the political system. It aims to demonstrate that dualistic perspectives, autonomous perspectives and dichotomous perspectives about spheres of civil society and the State need to be complemented by a dynamic perspective that understands

\footnotetext{
${ }^{1}$ Este artigo se baseia na tese de doutoramento da autora, intitulada "Movimentos sociais e instituições participativas: efeitos organizacionais, relacionais e discursivos" (CARLOS, 2012).

* Professora adjunta do Departamento de Ciências Sociais da Universidade Federal do Espírito Santo (UFES); doutora em Ciência Política pela Faculdade de Filosofia, Letras e Ciências Humanas (FFLCH) da Universidade de São Paulo (USP); mestre em Planejamento Urbano e Regional do Instituto de Pesquisas de Planejamento Urbano e Regional (IPPUR) da Universidade Federal do Rio de Janeiro (UFRJ); e pesquisadora do Núcleo Democracia e Ação Coletiva (NDAC) do Centro Brasileiro de Análise e Planejamento (CEBRAP). E-mail: euzeneiacarlos@gmail.com
} 
those spheres as fields in interaction. These fields are continuously made and their frontiers are fluid and blurred. An analytical articulation between civil society and the State is fundamental for understanding the imbrications and interconectivities among colective actors and political institutions, specially in democratic contexts where mediantion channels are institucionalized. This paper also proposes that the complexity and heterogeneity of contemporary social movements exposes the fallacy behind the caracterizations of coletive actors as pure, consistent and stable. In sum, it is necessary to recognize cultural and institutional dimensions of collective action involved in the interactions among these social actors and the State.

\section{Keywords}

Social movements. Political system. Societal state interactions.

\section{Introdução}

As interações entre movimentos sociais e sistema político têm recebido pouca atenção das Teorias dos Movimentos Sociais, dado que pressupõem uma separação rígida entre a sociedade civil e o Estado que prejudica uma análise de suas formas de interdependência e influência recíproca. Essas teorias têm pouco a dizer sobre a diversidade das interações dos movimentos com governos, agências estatais, partidos políticos ou outros atores políticosinstitucionais, assim como da natureza dessas inter-relações e de seus efeitos para os atores societários e institucionais.

Tanto a Teoria do Processo Político, ao enfatizar a ação coletiva como conflito político com os "detentores de poder" (McADAM; TARROW; TILLY, 2001; TARROW, 1997), quanto a Teoria dos Novos Movimentos Sociais, ao ressaltarem a sua descontinuidade com as modalidades tradicionais da política (MELUCCI, 1996; TOURAINE, 1985), descuidaram das relações constituídas entre a esfera societária e institucional. Essas teorias, de modo geral, abordam a sociedade civil e o Estado como esferas rigidamente separadas, estanques, autônomas e dicotômicas, ignorando tais esferas como produto de um processo dinâmico e contingente de mútua constituição. A compreensão dos movimentos sociais em sua relação com o sistema político, ao contrário, requer uma análise dinâmica que acentue os aspectos de coconstituição entre a sociedade civil e o Estado, como domínios que interagem e se influenciam mutuamente em um processo contínuo e circunstancial, cujas fronteiras são 
imprecisas e enevoadas (SKOCPOL, 1992; SOMERS, 1993).

Desse modo, ao desnudar um campo de relações e de implicações mútuas entre sociedade civil e Estado, o engajamento societário nas agências governamentais e a reconfiguração das interações socioestatais, no contexto brasileiro pós 1990, desafia as teorias dos movimentos sociais. Assumindo o pressuposto analítico de coconstituição entre sociedade e Estado como fundamental à compreensão das interconectividades e imbricações entre atores coletivos e instituições políticas, este artigo visa discutir a abordagem analítica da relação entre movimentos sociais e sistema político nas teorias dos movimentos sociais.

Na primeira seção, são introduzidos os pressupostos gerais da teoria do Processo Político e da teoria dos Novos Movimentos Sociais. Na segunda seção, são problematizados ambos os enfoques à compreensão dos movimentos sociais no contexto de interação com atores institucionais e as limitações das teses da institucionalização do movimento, tendo em vista a sua separação analítica entre sociedade civil e Estado. Na terceira, analisa-se a polarização do debate brasileiro dos movimentos sociais no contexto da transição democrática e as suas restrições a um entendimento complexo dos atores que reconheça conjuntamente as dimensões culturais e institucionais da ação coletiva. Nas considerações finais enfatiza-se a abordagem de coconstituição entre sociedade civil e Estado, fundamental à compreensão das interconectividades e imbricações entre atores societários e estatais.

\section{Teorias dos movimentos sociais: introduzindo o debate}

Os paradigmas estadunidense e europeu na análise dos movimentos sociais contemporâneos consagraram categorias analíticas de dimensões complementares da ação coletiva. No entanto, a divergência acerca dos pressupostos de cada um deles, expressa especialmente na polarização racionalidade versus expressividade e na oposição micro versus macro, frustrou uma síntese teórica. Desse modo, a aceitação da explicação concorrente ocorreu tão somente de modo acessório e parcial.

Na corrente estadunidense, as teorias da Mobilização de Recursos (MR) e do Processo Político (PP) centraram suas pesquisas nas condições de emergência, desenvolvimento e sucesso da ação coletiva, tomando como pressuposto a racionalidade da ação e o nível micro de análise. Em reação às 
teorias funcionalistas do comportamento coletivo, que enfatizavam o caráter irracional da participação e a mobilização como sintoma de disfunção do sistema social, os teóricos da Mobilização de Recursos defendem que a ação coletiva é fruto de um cálculo racional dos indivíduos sobre os custos e os benefícios da participação, cuja mobilização depende da posse de recursos materiais e não materiais disponíveis nas sociedades avançadas (McCARTHY; ZALD, 1973; 1977). Esses autores aplicaram a teoria de Mancur Olson, derivada dos grupos de interesse, à análise dos movimentos sociais. Com efeito, circunscreveram a motivação da ação coletiva ao nível individual e estabeleceram a solução do problema do free rider na profissionalização da organização do movimento. Nos termos de Canel (1992), a teoria da MR emprega um "modelo intencional" e explica os movimentos em referência ao nível de ação estratégica-instrumental adotada pelos atores no contexto de relações de poder e interação conflituosa.

A abordagem da MR recebeu crítica contundente de Sidney Tarrow que a acusou de inadequada para compreender os movimentos sociais e seus problemas. Tarrow reconheceu o caráter "social" - em vez de "individual" - do movimento, situou o problema peculiar da ação coletiva, resultante dos custos de transação, na coordenação das atividades e alocou a solução desse problema nas oportunidades políticas que criam incentivos externos aos movimentos (TARROW, 1997, p.33 e 63). Mantida a premissa de racionalidade e de ação estratégica, essa corrente se desdobrou na teoria do Processo Político (PP), a qual substitui a centralidade dada à mobilização de recursos econômicos e organizacionais pela dimensão política e cultural do movimento social. Desse modo, a ênfase recai sobre o papel do contexto político-institucional na emergência da ação coletiva. Seus principais expoentes priorizam a estrutura de incentivos e/ou constrangimentos políticos a partir da qual os atores são encorajados ou desencorajados a se engajar no confronto político. Conforme os teóricos sustentam, a estrutura de oportunidades políticas, como ambiente externo favorável, oferece as condições para o surgimento do movimento social, a qual se soma uma estrutura de mobilização, ou seja, de organizações formais, redes sociais e um esquema de interpretação simbólica denominado frame (TARROW, 1997; McADAM; TARROW; TILLY, 2001).

O paradigma europeu dos Novos Movimentos Sociais (NMS), em contraposição, vinculou os movimentos contemporâneos a uma perspectiva histórica de mudanças macroestruturais e de passagem para uma sociedade 
pós-industrial ou programada. ${ }^{2} \mathrm{O}$ reducionismo marxista, desse modo, foi deslocado em favor de uma abordagem teórica que privilegiasse os significados e as identidades do movimento social concebido como "conflito pelo controle social do modelo cultural dominante" (TOURAINE, 1985, p. 785). Opondo-se ao "racionalismo limitado", afirmou os movimentos como lutas no campo da produção simbólica e identitária, que constituem laços de confiança e de solidariedade e não se restringem às trocas, negociações ou cálculos estratégicos de custos e benefícios (MELUCCI, 1989; BUECHLER, 1995).

Sob essa perspectiva teórica, os movimentos são constructos sociais, cuja ação coletiva se estabelece mediante a interação de objetivos, recursos e obstáculos, em um sistema de oportunidades e coerções (MELUCCI, 1985, p.792). Esse modelo autorreflexivo contribui para a compreensão da razão pela qual os movimentos se constroem e os indivíduos criam laços de solidariedade, mesmo quando não serão diretamente afetados pelos benefícios alcançados (DELLA PORTA; DIANI, 2006). A luta dos atores coletivos, nesse sentido, não se restringe à sua inclusão no sistema de organização política ou à obtenção de benefícios materiais, mas envolve a construção de novas identidades, culturas, linguagens e hábitos, como um fim em si mesmo.

Em oposição à ação instrumental e à política institucional, os teóricos dos NMS ressaltam a natureza expressiva dos movimentos e seu campo de ação na sociedade civil: "os novos movimentos são caracterizados pela solidariedade e expressividade das relações em seu bojo, sendo secundários os objetivos instrumentais e a busca de vantagens dentro do sistema político" (MELUCCI, 1980, p.220). ${ }^{3}$ De acordo com Melucci $(1985 ; 1980)$, os novos movimentos direcionam sua ação à mudança dos códigos culturais e constituem um

\footnotetext{
2 "A sociedade pós-industrial deve ser definida de uma forma mais global e radical, como uma nova cultura e um campo para novos conflitos sociais e movimentos. (...) Somente a organização de novos movimentos sociais e o desenvolvimento de diferentes valores culturais podem justificar a ideia de uma nova sociedade que eu prefiro chamar de programada mais que uma sociedade pós-industrial” (TOURAINE, 1985, p.781-782, grifo no original).

${ }^{3}$ Em complemento, Melucci afirma em outra obra: "Eles [os novos movimentos] não lutam meramente por objetivos materiais ou para aumentar seus participantes no sistema. Eles lutam por suporte simbólico e cultural, por um significado e orientação diferente da ação social. Eles tentam mudar a vida das pessoas, eles acreditam que você pode mudar sua vida hoje ao lutar por mudanças mais gerais na sociedade" (MELUCCI, 1985, p.797).
} 
desafio simbólico ao modelo dominante, cuja chave de compreensão está no significado de sua identidade.

A contribuição central do paradigma europeu dos movimentos sociais está na ênfase à dimensão cultural da ação coletiva, ao processo de constituição de novas subjetividades e de novas identidades, bem como no realce da novidade dos movimentos contemporâneos ${ }^{4}$. Por sua vez, a corrente estadunidense avançou na explicação da dinâmica de mobilização do movimento, identificando os recursos, as estratégias, os formatos organizacionais e as oportunidades políticas que condicionam suas ações dirigidas ao sistema político, conforme avaliou Canel (1992). Melucci sintetiza a especificidade de ambas as abordagens nos seguintes termos: por um lado, as teorias estruturais explicam porque mas não como os movimentos se constituem e mantêm a própria estrutura; por outro lado, o enfoque estadunidense explica como mas não porque os movimentos se constituem; todavia, falha no exame do significado e a orientação deles.

O debate entre esses paradigmas foi tingido pela autodefesa de primazia explicativa, circunscrita à controvérsia estratégia versus identidade (COHEN, 1985). Resumidamente, a ênfase na racionalidade e estratégia da ação pelas teorias estadunidenses, ainda que favoreça a compreensão de questões fundamentais sobre os movimentos sociais - como se organizam, como processam a acumulação de recursos e como percebem e respondem a oportunidades do contexto político -, conduziu a uma análise refratária a outras dimensões da formação do ator coletivo. Tal corrente não ofereceu "meios adequados para explicar as novas formas de organização ou os projetos dos movimentos contemporâneos que simplesmente não têm como objetivo que a economia ou o Estado os inclua ou lhes conceda benefícios materiais" (COHEN; ARATO, 1992, p.562). O excessivo destaque dessa corrente teórica ao indivíduo racional que efetua cálculos estratégicos conduz à desconsideração do caráter expressivo da ação coletiva, como os processos de construção de solidariedades e identidades nas relações sociais, cuja orientação "responde a uma lógica do sistema do campo cultural e da vida cotidiana das pessoas" (MELUCCI, 2002, p.39-40).

\footnotetext{
${ }^{4}$ Para uma análise crítica da "novidade" dos novos movimentos sociais e da sua descontinuidade com as formas da política tradicional, ver Calhoun (1993), dentre outros.
} 
Na vertente europeia, a concentração exclusiva na análise da formação da identidade, em contraste com a análise das demandas materiais e redistributivas, também tende a limitar a compreensão do movimento social. Segundo Canel (1992, s/p), a abordagem dos NMS “explica o significado dos movimentos em referência aos processos estrutural, histórico, político e ideológico, mas não integra em sua análise a dimensão estratégicoinstrumental da ação social" concernente às decisões tomadas, às estratégias desenvolvidas e aos recursos mobilizados. Além disso, sem atentar para o caráter coconstituinte da cultura em sua relação com atores e estruturas diversas, a compreensão da identidade coletiva como forma cultural autônoma limita sua abrangência conceitual. A teoria dos NMS também tem pouco a dizer sobre a dimensão organizacional dos movimentos, uma vez que restringiu a análise a considerações acerca da descontinuidade com formatos organizacionais tradicionais, hierárquicos e não democráticos, ressaltando a novidade da espontaneidade dos movimentos sociais e a participação direta neles.

Todavia, essa polarização paradigmática entre as vertentes estadunidense e europeia foi seguida por um espírito de integração das abordagens, que marcou a última década do século findo. Conquanto não tenha resultado em uma síntese teórica, a avaliação de insuficiência e de compatibilidade de ambas as correntes motivou proposições de complementaridades: os teóricos dos NMS reconheceram a estratégia e a ação instrumental nos movimentos sociais (COHEN,1985; MELUCCI,1985; 2002), ao passo que os analistas da MR e do PP incorporaram a dimensão cultural da ação coletiva (McADAM; McCARTHY; ZALD, 1999; TARROW, 1997). Nessa convergência mínima entre os dois enfoques, ponderou-se que "as mobilizações envolvem tanto a ação estratégica, crucial para o controle sobre bens e recursos que sustentam a ação coletiva, quanto a formação de solidariedades e identidades coletivas" (ALONSO, 2009, p.72). Contudo, há limites nessa perspectiva de integração das abordagens teóricas. Estudiosos europeus têm postergado a admissão da estratégia em seus programas de pesquisa e, nos estudos americanos, predomina uma "instrumentalização da abordagem cultural", isto é, a cultura e os elementos simbólicos ou são vistos estritamente como ferramentas ou recursos acionados pelas organizações de movimentos, desarticulados da ideologia e das tradições discursivas, ou como meios para um fim, não significativos em si mesmos (ALEXANDER, 1998).

Os limites e desafios das abordagens dos movimentos sociais exigem tensionar os seus paradigmas em seus próprios termos, de modo a "esclarecer 
a importância das práticas interpretativas e do meio cultural e que, ao mesmo tempo, mostre como estes aspectos se inter-relacionam com fatores institucionais e históricos" (ALEXANDER, ibid., p.122). As perspectivas dos movimentos sociais, nesse sentido, deveriam reconhecer as dimensões da ação coletiva frequentemente polarizadas - cultural-institucional, sociedade-Estado, expressivo-estratégico - como campos que coexistem e se coconstituem em processos sociais dinâmicos e interativos.

\section{Movimento social e sistema político nas teorias dos movimentos sociais}

Os movimentos sociais desenvolvem relações complexas e diversificadas com o sistema político e, na relação com o Estado, em vez de constituírem modelos puros, coerentes e estáveis, muitos deles combinam dimensões multifacetadas da ação coletiva. Considerando as múltiplas possibilidades de interação dos movimentos com o sistema político, como as teorias dos movimentos sociais compreendem o engajamento societário nas instituições

do Estado? Como essas teorias analisam os efeitos do contexto de interação com as instituições para os movimentos sociais?

A separação analítica entre sociedade civil e Estado, nas teorias dos movimentos sociais, restringe a compreensão dos movimentos em processos de interação com atores institucionais, pois dificultam o reconhecimento do caráter coconstituinte, de influência mútua e de interpenetração entre movimentos e Estado.

$\mathrm{Na}$ teoria do PP a institucionalidade política assume proeminência. Os analistas dessa corrente a correlacionam à emergência e ao sucesso do movimento social, inquirindo acerca dos efeitos da "estrutura de oportunidades políticas" no surgimento da ação coletiva, da susceptibilidade do movimento para representar demandas sociais e da sua capacidade de influir nas instituições políticas no sentido de torná-las acessíveis aos seus reclamos (McADAM; TARROW; TILLY, 2001). Contudo, o pressuposto analítico da separação entre sociedade civil e Estado inibe esses teóricos de explorar a diversidade de conexões entre movimentos sociais e o sistema político, mantendo invisíveis certos tipos de relações entre atores coletivos e o Estado (VON BÜLLOW; ABERS, 2011). Por um lado, se esse enfoque valorizou as condições político-institucionais de surgimento e êxito do 
movimento, por outro, enublou as interações que estabelecem coletividades e instituições políticas e sequer problematizou os termos de sua mútua constituição, sendo raros e limitados os estudos acerca dos efeitos na ação coletiva em decorrência de sua interação com instituições políticas e agências estatais.

Nessa perspectiva do PP, prepondera na análise da relação entre movimentos sociais e sistema político a contestação das instituições políticas, e não as interações com o Estado e os detentores de poder (JENKINS, 1995). Ainda que o Estado tenha recebido centralidade nesse modelo analítico, os estudiosos sublinham as oportunidades políticas e sociais sob as quais "desafiadores" contestam o poder na arena político-institucional (TARROW, 1997; TILLY, 1978). Nessa abordagem, a relação dos movimentos sociais com a institucionalidade política compreende a sua integração no sistema, evidenciada particularmente pelo reconhecimento dos movimentos como atores políticos e pela obtenção de seus objetivos demandados ao Estado. O caráter contestatório e desafiador dos movimentos em direção aos detentores de poder é compreendido em termos de um modelo conflituoso de ação, construído dentro das relações de poder do sistema político e que implica conflito de interesse entre atores não institucional e institucional (COHEN, $1985)^{5}$.

Esse modelo conflituoso de ação coletiva contém restrições à análise da relação entre os movimentos sociais e o Estado, particularmente, por três razões. Em primeiro lugar, em termos de alocação de objetivos e de acesso ao mercado político, essa interpretação ignora demandas que não são direcionadas ao Estado, que, em geral, remetem ao significado cultural e simbólico dos movimentos sociais (MELUCCI, 1985; DELLA PORTA; DIANI, 2006). Em segundo lugar, esse modelo restringe a política ao universo institucionalizado, limitando a compreensão da dimensão política do movimento. Assim, negligencia que o campo seja alargado através da

\footnotetext{
${ }^{5} \mathrm{~A}$ ênfase da teoria do processo político no conflito com atores institucionalizados está presente desde o trabalho seminal de McAdam, que afirma: "O modelo do processo político é baseado na noção de que a ação política de membros estabelecidos do sistema político reflete um conservadorismo persistente. Eles trabalham contra a admissão no sistema de grupos cujos interesses contrariem significativamente seus próprios interesses" (McADAM, 1982, p.38). Na explicação de Toni (2001), esses teóricos concebem as elites políticas como inimigas e não aliadas aos grupos insurgentes, em contraposição à teoria da mobilização de recursos que confere centralidade ao papel das elites na mobilização.
} 
proliferação de múltiplos espaços politizados na sociedade civil (MOUFFE, 1988) e que a cultura dos movimentos como expressão política redefina o poder social (ALVAREZ; DAGNINO; ESCOBAR, 2000). Por fim, sob essa perspectiva, as possibilidades de relações dos movimentos com o Estado são reduzidas e circunscritas às interações de poder conflituosas, desprivilegiando aquelas interações cooperativas ou colaborativas entre atores societários e institucionais em torno da produção de políticas públicas ou de alianças com partidos políticos, conforme destacam Goldstone (2003), Giugni e Passy (1998) e Hanagan (1998).

Essa teoria do processo político, em complemento, pressupõe que o contexto político no qual os movimentos operam, suas instituições e agentes estatais, compreende um ambiente externo aos atores coletivos. Essa abordagem desconsidera que o "ambiente" constrói oportunidades e constrangimentos à ação coletiva ao mesmo tempo que é construído e influenciado pelo processo de interação entre atores societários e institucionais. Desse modo, o reconhecimento da interdependência é fundamental à apreensão das relações complexas e diversificadas entre os atores de ambos os campos, tanto fora quanto dentro do sistema político.

Na teoria dos NMS, por sua vez, a relação do movimento social com o aparato político-institucional é concebido em termos de sua novidade e descontinuidade com atores políticos tradicionais. Essa abordagem enfatiza a natureza expressiva dos novos movimentos e concebe as coletividades como um desafio simbólico aos padrões culturais dominantes, voltado às transformações na sociedade em vez de direcionado ao sistema político. Sob essa perspectiva, os novos movimentos não operam no nível estratégicoinstrumental, concernente à reprodução e distribuição material, ou à integração no sistema político; mas, no ao nível comunicativo da ação, concernente à reprodução cultural, à socialização e à integração social (HABERMAS, 1981 apudCANEL, 1992). Os novos movimentos, nesse sentido, criam novos significados culturais, novas identidades e reinterpretam normas e valores, em um processo autorreflexivo que produz mudança sobre si mesmo. Na afirmação de Touraine (1985, p.780), "o movimento se constitui no campo da sociedade civil e está voltado para a produção cultural”; ou ainda, o "movimento social é menos sociopolítico e mais sociocultural". Melucci (1985; 1980) também concorda que os novos movimentos representam um desafio simbólico e cultural, que a solidariedade e a expressividade das relações em seu bojo caracterizam sua novidade e que eles não são orientados para o Estado, mas para um campo de autonomia vis-à-vis o sistema político. 
Nas palavras de Melucci:

Os novos movimentos não estão focados no sistema político. Eles não são orientados em direção a conquista de poder político ou o aparato do Estado, mas antes em direção ao controle de um campo de autonomia ou de independência vis-à-vis o sistema. Os novos movimentos são caracterizados pela solidariedade e expressividade das relações em seu bojo, sendo secundários os objetivos instrumentais e a busca de vantagens dentro do sistema político. (MELUCCI, 1980, p.220)

Nessa compreensão dos novos movimentos, orientada para a sociedade e detidamente cultural, é pressuposta a proeminência dos atores societários no processo de mudança social ante os sistemas e as instituições, de modo que a centralidade é conferida aos movimentos sociais e não aos arranjos institucionais (TOURAINE, 1988). Esses teóricos assumem como referência um quadro de perda estrutural de "responsividade" das instituições estabelecidas e de "incapacidade de aprendizado" das instituições. Conforme a explicação de Offe acerca da teoria dos novos movimentos sociais: “o 'novo' paradigma está claramente conectado a uma visão de realidade social que é caracterizada pela ampliação das privações e do mal funcionamento, pelo aprofundamento do controle e pelo diagnóstico de bloqueio institucional à capacidade de aprendizado" (1985, p.853).

Essa noção de descontinuidade e de oposição entre sociedade civil e Estado na teoria dos NMS produz limitações à compreensão dos movimentos no bojo das relações com o sistema político, especialmente, em três aspectos. Em primeiro lugar, essa abordagem desconsidera que muitos movimentos assumem uma dimensão político-institucional vocalizando demandas instrumentais ao sistema político e reivindicando ações ao Estado. Em segundo lugar, ela ignora aqueles movimentos que almejam o sistema político, reduzindo toda ação coletiva ao nível societário, ignorando o Estado como uma arena de luta e de atuação de certos movimentos e menosprezando a luta política fora ou dentro do Estado. Em terceiro lugar, essa concepção pressupõe uma autonomia nas orientações dos atores coletivos, atribuindo centralidade aos novos movimentos como campo cultural independente caracterizado por novas identidades coletivas e novas subjetividades, que a impede de reconhecer a influência mútua exercida entre ambos os campos da sociedade e do Estado.

A relação entre movimentos sociais e instituições políticas requer uma 
compreensão dinâmica que acentue os aspectos de coconstituição entre sociedade e Estado, como esferas que interagem e se influenciam mutuamente em um processo contínuo e circunstancial, conforme acentuado. Essa perspectiva é particularmente relevante à análise de movimentos que interagem com instituições do Estado, na medida em que concebe sociedade e Estado como produtos de um processo dinâmico e contingente de mútua determinação. Nas teorias do PP e dos NMS, a análise da sociedade e do Estado a partir de categorias estanques, autônomas e dicotômicas é, nesse sentido, limitada à explicação das interações entre atores societários e institucionais.

Predomina, nessas teorias, a acepção de movimento social como protesto público e participação outsider ou não institucionalizada, cuja chave analítica restringe igualmente a compreensão do movimento em sua interação com a institucionalidade política, na medida em que impõe duas implicações: (i) dificulta o reconhecimento das interações mutuamente constitutivas entre o movimento e o sistema político (agências do governo, partidos políticos e o Estado) e da combinação circunstancial entre modalidades de ação outsider e insider ou institucionalizada e (ii) interpreta o engajamento em instituições políticas como decorrente de um processo de institucionalização do movimento que afeta, exclusiva e homogeneamente, a dimensão organizacional da ação coletiva. A perspectiva cíclica e dicotômica dessa abordagem desconsidera a complexidade das mudanças e reconfigurações na ação coletiva ao longo do tempo, assim como a capacidade dos movimentos em combinar elementos complementares e híbridos na relação sociedadeEstado.

Além disso, nessas teorias, o protesto público é identificado à fase de intensa mobilização coletiva e atividade extrainstitucional, comumente denominada "ondas de mobilização" ou "ciclos de protesto", de caráter efêmero e cíclico, na qual o movimento social é "caracterizado pela exposição de seus objetivos através de ação direta disruptiva contra as elites, as autoridades e outros grupos ou códigos culturais" (TARROW, 1997, p.22). Conforme essa concepção, os movimentos defendem seus interesses por vias não institucionalizadas e invocam, potencialmente, o uso da força e/ou da coerção, incorporando uma natureza política outsider ao sistema político (GAMSON, 1990; DALTON; KUSCHLER, 1990).

Esse debate em torno da natureza não institucionalizada do protesto público enfatiza a distinção entre o modo de ação do movimento social e o de outros atores políticos em virtude do primeiro adotar um modelo de 
comportamento político considerado "incomum", em contraste com estilos de participação política convencionais, tais como os partidos políticos e os grupos de interesse. ${ }^{6}$ Segundo Goldstone (2003), a perspectiva de separação entre movimentos sociais e a política institucionalizada é favorecida pela definição dos movimentos como "desafiadores" que buscam acesso à esfera institucionalizada dos atores políticos convencionais, detentores do poder político (TILLY, 1978). Se, por um lado, tal abordagem contribui para o reconhecimento da especificidade dos movimentos sociais em face de outros atores políticos, por outro, ela obstrui o reconhecimento das interações e influência mútua entre os atores coletivos, as instituições políticas e os agentes governamentais.

Ao contrário dessa concepção que identifica movimentos sociais como protesto e ação outsider, estudos recentes acerca da interpenetração entre movimentos e instituições refutam a tese que distingue o movimento como estratégia extrainstitucional, argumentando que muitos movimentos interagem, constituem relações e formam alianças com partidos políticos, igrejas, agências do Estado e poder judiciário (GOLDSTONE, 2003; MISCHE, 2008). ${ }^{7} \mathrm{Na}$ análise dos impactos dos movimentos na gênese de partidos políticos e na formação de governos de esquerda, estudiosos acentuam o processo de imbricação entre instituições do Estado, partidos políticos e movimentos sociais, mediante o qual a estrutura das instituições e os movimentos sociais são mutuamente influenciados (GOLDSTONE, ibid.). Embora alguns movimentos se identifiquem como revolucionários claramente outsiders e como opositores às instituições estabelecidas, muitos outros mantêm relações ativas com atores políticos e institucionais, em diferentes contextos históricos e em processos dinâmicos de coconstituição. ${ }^{8}$

\footnotetext{
${ }^{6}$ Cabe ressaltar, no entanto, que diferente dos teóricos dos novos movimentos sociais que enfatizam sua novidade em relação aos atores coletivos e políticos tradicionais, no que tange tanto ao seu modo de ação quanto ao seu significado político, os analistas da mobilização de recursos e do processo político consideram esta distinção apenas em termos da estratégia de ação, argumentando que não há nenhuma descontinuidade fundamental entre movimentos sociais e a política institucional (McADAM; TARROW; TILLY, 2001), na medida em que ambos implicam conflito de interesse construído dentro das relações de poder institucionalizado.

7 No Brasil, no contexto pós-transição, ver os estudos empíricos: CARLOS (2012) e DOWBOR (2012).

${ }^{8}$ No Brasil, no período de transição do regime autoritário, estudos que enfocam a relação entre setores progressistas da igreja católica e movimentos sociais, podem ser encontrados em Doimo (1995) e Sader (1988); a relação entre movimentos sociais e o Partido dos Trabalhadores (PT), em Sader (1988); e a interação entre o movimento estudantil e o PT, em Mische (2008).
} 
Os movimentos sociais, assim, não estão fixados por princípio a uma forma de ação determinada (RASCHKE, 1994), podendo desenvolver, circunstancialmente, diferentes padrões de ação coletiva e combiná-los de forma multivariada - protestos públicos, ações institucionalizadas, alianças com políticos, partidos e agências do Estado.

De fato, a fronteira entre política não institucionalizada e política institucionalizada é pouco clara (GOLDSTONE, ibid.; 2004), e a permeabilidade entre ambas as esferas exaure o sentido da distinção entre movimento outsider e movimento insider defendido pelas perspectivas dicotômicas da ação coletiva. São diversificadas as modalidades de ação que os movimentos sociais podem desenvolver em contextos políticos diversos. Certos movimentos, transcendendo as delimitações de um evento específico, reúnem diferentes ocorrências, manifestações e práticas de atores individuais, organizacionais e institucionais ao longo de um continuum no tempo. Durante a trajetória, os movimentos desenvolvem a habilidade de combinar padrões de interação complementares e híbridos, como o conflito e a cooperação na relação sociedade-Estado. Essas configurações dos atores coletivos e o seu deslocamento temporal não significam, necessariamente, a persistência dos mesmos elementos representativos da ação coletiva de um contexto específico, mas a permanente reelaboração e ressignificação contextualizada.

A caracterização do movimento social como fenômeno cíclico e extrainstitucional tende a associar o engajamento institucional de atores societários e a interação com o Estado a um processo de "institucionalização do movimento". A teoria do Processo Político desenvolveu as abordagens mais influentes acerca da institucionalização dos movimentos, concebida como a sua integração às estruturas do Estado, a mudança no repertório de confronto e a busca de benefícios concretos através da negociação e acordo (TARROW, 1997; McADAM; TARROW; TILLY, 2001) ${ }^{9}$. Nesse enfoque, a institucionalização do movimento produz efeitos de complexificação em

\footnotetext{
${ }^{9}$ Ao passo que a abordagem dos NMS pouco tem a dizer a respeito das reconfigurações dos movimentos ao longo do tempo, decorrentes da inserção institucional e de interconexões deles com o Estado. Conforme ponderou Offe (1985), poucos teóricos admitem que os novos movimentos possam, partindo da sociedade civil e representando interesses construídos em seu âmbito, agir em um nível político-institucional; ou ainda, que os movimentos desenvolvam, em complemento às ações extrainstitucionais, formas de ação institucionalizada e de construção de alianças com atores do Estado.
} 
sua estrutura organizacional, expressos pela rotinização, burocratização e profissionalização da ação coletiva (MEYER; TARROW, 1998; KRIESI, 1999). A complexificação organizacional do movimento traria como consequências a mudança em seus objetivos de fundação, a desmobilização dos militantes, a cooptação dos ativistas e a sua transformação em grupos de interesse ou partidos políticos. Esta noção de institucionalização do movimento é defendida nos seguintes termos:

O padrão de institucionalização é quase o mesmo em todo lugar: à medida que acaba o entusiasmo da fase disruptiva de um movimento e a política se torna mais hábil em exercer o controle, os movimentos institucionalizam suas táticas e tentam obter benefícios concretos para seus apoiadores através de negociação e acordo - um caminho que frequentemente é bem-sucedido ao custo de transformar o movimento em um partido ou grupo de interesse. (TARROW, 2009 [1998], p.134).

Embora com limitada comprovação empírica, a institucionalização é definida, então, como: "a criação de um processo repetitivo que é essencialmente autossustentável, no qual todos os atores relevantes possam recorrer a rotinas bem-estabelecidas e familiares" (MEYER; TARROW, 1998, p.21). Desse modo, a institucionalização compreende três componentes principais: 1) rotinização da ação coletiva - ativistas e autoridades aderem a um script comum e modelo previsível de ação; 2) inclusão e marginalização - ativistas institucionalmente orientados são recompensados com acesso ao sistema político, ao passo que outros ativistas, comprometidos com desafios mais abrangentes e evitando o compromisso inerente à política institucional, se arriscam à repressão ou à marginalização e 3) cooptação - ativistas modificam suas reivindicações e táticas para que possam perseverar dentro da política institucional. O termo institucionalização, por fim, é remetido à profissionalização do movimento, quer dizer, as habilidades relativas à organização e à comunicação entre os ativistas dos movimentos tornam-se cada vez mais profissionais.

No entanto, essa noção opera sem introduzir uma distinção que lhe é fundamental, qual seja, entre a institucionalização do canal de mediação com o Estado e aquela do movimento. E, ao não fazê-lo, estabelece uma relação causal mecânica e unívoca entre institucionalização da mediação e a do ator coletivo. Tal compreensão torna-se, portanto, inábil para objetar em que medida a primeira geraria características institucionais no comportamento 
do ator, assim como para captar as regularidades e variações na relação entre as instituições e os atores sociais. Por esse motivo, em vez de assumir, a priori, que a institucionalização do canal de mediação gera a do movimento, é necessário submeter à verificação empírica os efeitos da primeira sobre os padrões de ação coletiva, pois, entre outras razões, o movimento pode ser altamente organizado, formalizado e profissionalizado também nos ciclos de protesto público, mesmo que sob o manto de narrativas de espontaneidade.

Em particular, a ênfase da teoria do PP na estrutura organizacional do movimento conduziu a uma visão estreita de institucionalização definida em termos de complexificação institucional, a qual é remetida à rotinização, previsibilidade, formalização, profissionalização, desmobilização e oligarquização da ação coletiva. ${ }^{10}$ Conforme estudo de Carlos, essa perspectiva, por um lado, desconsidera a diferenciação nos padrões organizacionais, tendo em vista as possibilidades de combinação entre complexificação organizacional e mobilização, em processos de engajamento em instituições de formato inovador. Por outro lado, dimensões complementares na configuração dos movimentos são ignoradas, como as dinâmicas relacionais e suas possibilidades de diversificação da rede de relações sociais no contexto de interações socioestatais, assim como os processos discursivos e identitários de significação e reconfiguração da relação com o Estado. (CARLOS, 2012)

Em suma, essa perspectiva do PP assume visão homogeneizante dos padrões de institucionalização: ativistas e autoridades aderem a um modelo previsível de ação, atores sociais institucionalizados têm acesso ao sistema político, são cooptados, mudam as suas reivindicações e perdem a sua autonomia, ao passo que são oprimidos e marginalizados aqueles que evitam os compromissos da política institucional (MEYER; TARROW, 1998) ${ }^{11}$.

No entanto, a relação entre movimentos sociais e Estado é mais complexa e multifacetada (DOOWON, 2006). Evidências empíricas demonstram que

\footnotetext{
${ }^{10}$ Grosso modo, os trabalhos que associaram complexificação organizacional do movimento social com burocratização, desmobilização e descolamento das bases sociais (PIVEN; CLOWORD, 1979; McCARTHY; ZALD, 1973, entre outros) seguiram o modelo de oligarquização das organizações de massas de Robert Michael (1962).

${ }^{11}$ Frequentemente, ambas as teorias dos movimentos sociais (PP e NMS) correlacionam o protesto público e a ação extrainstitucional ao comportamento autônomo dos atores e à sua coerência entre os fins e os meios, ao passo que a sua interação com a política institucional é comumente avaliada como dependente e cooptada.
} 
as mudanças e reconfigurações na ação coletiva, ao longo do tempo, são heterogêneas e multidimensionadas, as interações socioestatais são variadas e podem combinar elementos aparentemente contraditórios, como o conflito, a cooperação e a autonomia (CARLOS, ibid.). Do mesmo modo, a interação de movimentos sociais com a esfera estatal não significa, necessariamente, a perda de autonomia decisória, conforme demonstrado no estudo do movimento feminista paraguaio (SZWAKO, 2012).

Mais do que assumir as variações nos padrões de interação socioestatal como expressão da ambiguidade e contradição dos movimentos, é necessário avançar na investigação empírica, no intuito de compreender os significados das diferentes modalidades de ação para as coletividades, bem como as condições sob as quais os movimentos sociais assumem (e combinam) cada uma dessas caracterizações - o protesto público e a estratégia institucional; o conflito, a cooperação e a autonomia - e, não menos, os seus efeitos para os atores e as políticas imbricados.

\section{Movimentos sociais no Brasil contemporâneo: debates teóricos no contexto de transição democrática}

No Brasil, a insurgência de uma multiplicidade de movimentos sociais no final dos anos 1970, no contexto de transição do autoritarismo e de redemocratização, motivou inúmeros estudos que saudaram essas mobilizações como "demonstrações da força latente das classes subalternas" em confronto com os aparelhos do Estado (CARDOSO, 1983, p. 318). Oriundos de reformulações do marxismo clássico e da abordagem europeia dos NMS, os enfoques teóricos predominantes nas décadas de 1970 e 1980 enfatizaram as condições objetivas de emergência do movimento e do seu potencial de transformação das estruturas sociais, assim como sublinharam sua identidade e signo da mudança sociocultural da sociedade. Contudo, esses teóricos não trataram satisfatoriamente a relação entre os movimentos e o campo político-institucional, pois enfocaram o traço extrainstitucional dos primeiros e a sua autonomia em relação às instituições políticas tradicionais. O pressuposto dicotômico na relação do movimento com o Estado, presente nessa corrente teórica que orientou preponderantemente as interpretações daqueles movimentos sociais, postergou o exame das interações entre a sociedade civil e a institucionalidade política. 
Os primeiros estudos dos analistas brasileiros, na conjuntura política do final dos anos 1970, foram inspirados nos trabalhos de Manuel Castells sobre os "movimentos sociais urbanos" e no enfoque do autor sobre as lutas urbanas como desdobramento da luta de classes no capitalismo monopolista avançado, no bojo da teoria dos $\mathrm{NMS}^{12}$. Os movimentos sociais urbanos são concebidos pelo autor como "sistemas de práticas sociais contraditórias que põem em causa a ordem estabelecida, a partir das contradições específicas da problemática urbana" (CASTELLS, 1976, p.10). De acordo com essa perspectiva, em decorrência das chamadas "novas contradições urbanas", um processo de politização do cotidiano se institui e emerge uma nova forma de conflito social ligado à organização coletiva do modo de vida, em um quadro de contrastes e desordens com potencial de transformação da ordem estabelecida, assim definido:

É um quadro cheio de contrastes e confuso em que se misturam as novas contradições sociais e o escotismo, a recusa de novas formas de opressão e o passadismo, a luta revolucionária e a defesa do estatuto social de vizinhança. Em qualquer dos casos quando, de dia para dia, em todos os países se vê aumentar o número, a dimensão e a intensidade das mobilizações populares, atacando o 'esquema de vida', as formas e os ritmos da vida quotidiana, parece lógico deduzir a emergência de uma nova forma de conflito social diretamente ligado à organização coletiva do modo de vida. (CASTELLS, ibid., p.10).

Nesse paradigma teórico, o autor define que "a verdadeira origem da mudança e da inovação da cidade está nos movimentos sociais urbanos e não nas instituições”, mesmo confesso da incerteza das possibilidades de transformações do urbano sem a correspondente mudança nos planos social e político (ibid., p.17). Também define que toda intervenção do Estado na organização da vida social obedece à lógica das forças sociais dominantes, desse modo, o Estado permanece não como instrumento de mudança social, mas de dominação, de integração e de regulação das contradições estruturais.

\footnotetext{
${ }^{12}$ As principais referências teóricas para o estudo dos chamados "movimentos sociais urbanos" incluía, além de Castells, Lojkine e Borja (Cf. JACOBI, 1987; CARDOSO, 1983; MACHADO; RIBEIRO, 1985).
} 
Castells introduz uma distinção analítica entre as dimensões da luta política, particularizando a luta política institucional da luta política extrainstitucional, essa última considerada inovadora nos meios para a expressão da luta popular. Por um lado, se essa abordagem vislumbra novas formas de conflito social corporificadas em movimentos das "classes populares", por outro, instaura uma polarização entre sociedade civil e Estado, ao sobrevalorizar o papel daquela como transformadora dos modos de vida e ao subestimar a capacidade de reconfiguração do último.

Inúmeros foram os estudos acerca dos movimentos sociais no país inspirados nesse enfoque teórico. A despeito das diferentes gradações analíticas, as interpretações da década de 1970 construíram uma percepção de novidade histórica da prática desses movimentos, anunciando seu potencial de transformação social e seu papel no contexto da sociedade (TELLES, 1987). Os autores identificaram nos movimentos: (i) a derivação de sua emergência das "contradições da problemática urbana", ante as novas necessidades de reprodução da força de trabalho e ante a política do poder público direcionada aos interesses dos capitalistas; (ii) o caráter de classes populares, a constituição de novos sujeitos coletivos e de luta histórica como expressão de resistência, tomada de posição e de consciência; (iii) a espontaneidade nas formas de organização, nas estratégias de mobilização e na contraposição ao sistema institucional; (iv) a visão de Estado autoritário e opressor que busca transformar os movimentos em mecanismos de dispersão das contradições; e (v) o padrão de autonomia em face do Estado e da institucionalidade política em geral ${ }^{13}$.

Essa abordagem analítica, no início da década de 1980, acendeu muitas controvérsias e críticas de estudiosos descrentes nas teorias macroestruturais, especialmente em três aspectos, sejam estes, a explicação da emergência dos movimentos como decorrente das contradições do capitalismo, o seu caráter de classe popular e transformador das estruturas sociais e, o approach extrainstitucional e autônomo dos movimentos. Esse último ponto alimentou a maior divergência na literatura nacional entre os enfoques comumente denominados "culturalista" e "institucionalista", sobre a qual nos deteremos com mais vagar.

${ }^{13}$ Estudos representativos desta abordagem podem ser encontrados em José Álvaro Moisés (1982), Mª Glória Gohn (1982; 1988) e Paul Singer (1981), dentre outros. 
No que se refere ao primeiro elemento, a derivação da emergência dos movimentos das "contradições urbanas" recebeu crítica contundente de Lúcio Kowarick que a denominou "deducionismo das condições objetivas". $\mathrm{O}$ autor afirmou que o surgimento da ação coletiva não pode ser deduzido imediata e exclusivamente - da urbanização acelerada e das mazelas sociais e que as suas motivações precisam ser buscadas não somente na estrutura material que afeta as condições de vida dos grupos envolvidos. Nas palavras do autor:

Não considero possível deduzir as lutas sociais das determinações macroestruturais, posto que não háligaçãolinear entre precariedade das condições de existência e os embates levados adiante pelos contingentes por ela afetados. Isto porque, malgrado uma situação variável mas comum de exclusão socioeconômica, os conflitos manifestam-se de maneira diversa e, sobretudo, as experiências de luta têm trajetórias extremamente dispares, apontando para impasses e saídas para os quais as condições estruturais objetivas constituem, na melhor das hipóteses, apenas um grande pano de fundo. (KOWARICK, 1984, p.81).

Outros analistas, enfatizando o peso do Estado e das instituições na ascensão dos movimentos, defenderam que a explicação da emergência dos movimentos sociais reside na inoperância do Estado no provimento dos serviços coletivos, o que impulsionaria a totalidade dos atores coletivos à ação em prol da ampliação de sua cidadania. Em outras palavras, "os movimentos, enquanto expressões de luta pelos direitos de cidadania, constituíram uma resposta à própria violência institucional do Estado que afeta essas populações na esfera do seu cotidiano" (BOSCHI; VALLADARES, 1983, p.140). Para esses autores, o aparato estatal também é o motor da contenção desses movimentos, materializado no processo interativo de negociação que se desenvolve entre ambas as partes em torno da concretização dos direitos reivindicados. No geral, nessa perspectiva, o Estado sufoca as iniciativas originárias da sociedade com seu intervencionismo.

O suposto conteúdo de classe social dos movimentos e a noção de "classes populares", como dito, também constituíram alvo de críticas de estudiosos de diferentes campos teóricos (BOSCHI; VALLADARES, ibid.; BOSCHI, 1987; CARDOSO, 1983; 1987; DURHAM, 1984). O predomínio das camadas populares ou dos setores sociais empobrecidos na base social dos movimentos foi reconhecido por muitos analistas que, no entanto, discordando de 
sua vinculação a uma identidade de classe, associaram tal predomínio às demandas por bens de consumo coletivo, por espaço de moradia, entre outras necessidades básicas do cotidiano. No entanto, a heterogeneidade social e a complexidade dos objetivos que caracterizam esses movimentos também tornam demasiadamente restritos os conceitos relativos à esfera do consumo coletivo, como explica Durham (1984). Em complemento, evidências de fragmentação, desarticulação e desmobilização dos movimentos, no contexto de abertura política, pluripartidarismo e eleições, fortaleceram os questionamentos acerca da unidade identitária dos movimentos e de seu caráter transformador das estruturas sociais, conduzindo a importantes deslocamentos interpretativos na literatura predominante $\mathrm{e}^{14}$.

A partir de novas tendências do marxismo na teoria dos NMS, a conceituação estrutural das classes sociais forneceu passagem ao estudo de atores específicos e a aceitação dos valores sociais e da cultura como elementos básicos à compreensão da dinâmica dos movimentos. Nessa inflexão, nota-se que a categoria "processo" foi valorizada em face da categoria "estrutura". Na reelaboração da concepção de cultura, "a negatividade implícita na análise marxista tradicional foi substituída por uma visão positiva que enfatizava a autonomia criativa, a capacidade de reelaboração simbólica e a negociação, como traços das práticas culturais dos setores subalternos" (DAGNINO, 2000, p.76). A partir disso, a diversidade e a heterogeneidade da vida coletiva ganhariam relevo com a incorporação da dimensão cultural e social nos estudos, em detrimento das análises reducionistas e totalizantes que "omitam o sentido de situações particulares e específicas em nome da necessidade de generalização dos efeitos das práticas sociais" (RIBEIRO, 1991, p.98).

A partir dessa transposição do enfoque de classes sociais para o campo da cultura, como considerou Paoli (1995), a análise dos novos movimentos sociais como sujeitos políticos autônomos e do seu significado político, incorporando a noção de identidade coletiva e os discursos dos atores, contribuiu para a qualificação dos sujeitos políticos como plurais e diversificados e de suas práticas como autônomas. O potencial dos movimentos na renovação dos padrões socioculturais e na criação de uma "cultura política igualitária e democrática" emerge nessa via de interpretação, tendo se expressado

\footnotetext{
${ }^{14}$ Nos movimentos da década de 1970, o social era concebido "como espaço homogêneo, linear e indiferenciado, como 'espaço de liberdade' contra a opressão vinda do Estado", conforme apontou criticamente Vera Telles (1987, p. 75).
} 
na dinâmica dos movimentos, sobretudo, na questão dos "direitos a ter direitos" e de uma "nova cidadania". De acordo com essa perspectiva, mesmo coexistindo com as antigas formas de representação política integradora, assistencialista e clientelista, as novas formas de participação da sociedade civil contribuiriam para a formação de um novo tecido social no qual desponta uma "nova cultura política" (GOHN, 2002; EVERS, 1984). Em outras palavras, os movimentos, espontaneamente organizados, constituiriam “'novos sujeitos políticos', portadores de uma 'nova identidade sociocultural', com contornos de projeto político voltado para a transformação social e a radical renovação da vida política" (DOIMO, 1995, p.48). Nesse contexto teórico, o conceito de identidade coletiva de Alberto Melucci e a ênfase na base cultural do conflito oriunda das ideias de Antonio Gramsci tornaram-se predominantes. ${ }^{15}$

O reconhecimento dos processos de diferenciação dos movimentos e de sua pluralidade, complexidade e ambiguidades geraria contribuições fecundas à corrente analítica “culturalista”. Porém, a ênfase da maioria dos estudos nos discursos unitaristas, em prejuízo da diversidade e dos conflitos internos nos processos de constituição dos sujeitos, assim como a substantivação da noção de identidade coletiva, tanto por sua redução à ideia de unidade de interesses quanto pela perda do seu caráter relacional, reforçaram a tendência classificatória que define o "novo" em contraste ao "tradicional" (CARDOSO, 1987).

Além disso, a argumentação de autonomia dos atores coletivos na relação com o Estado e de negação da institucionalidade política foi alvo de duras críticas de autores céticos do impacto dos movimentos sobre o sistema político. Esses autores, por outro lado, enfatizavam as interações de negociação dos movimentos com agências governamentais e de alianças com partidos políticos. Para os intérpretes que defendiam a independência e o caráter não institucionalizado dos movimentos, no plano simbólico, o discurso "contra o Estado" permitia aos atores coletivos pensar-se de modo autônomo, em vez do imaginário pretérito de passividade, manipulação e de relações clientelísticas com a dinâmica estatal (TELLES, 1987; PAOLI, 1995). O discurso de apartidarismo dos movimentos e o ocultamento das

${ }_{15}$ Para uma análise das contribuições de Gramsci à renovação do marxismo estruturalista e da influência de seus conceitos de hegemonia, transformação social e sociedade civil nos estudos de movimentos sociais, ver Dagnino (2000). 
conexões que envolvem posições partidárias, por sua vez, correspondiam "ao processo interno de eliminação das diferenças entre os participantes, na criação (mítica) da comunidade dos iguais", segundo avaliou Durham (1984).

A reafirmação da qualificação das coletividades como espontâneas, autônomas e antagônicas ao Estado, cujo approach não institucional do paradigma dos NMS permaneceu praticamente intocado no interior dessa corrente, instaurou uma polarização teórica com o enfoque centrado no papel do Estado e das instituições nos contornos da ação coletiva conhecida como a controvérsia "autonomia versus institucionalização"16.

Os analistas críticos das interpretações correntes recolocaram na agenda a questão dos efeitos político-institucionais da ação coletiva sobre o sistema político, relativizando significativamente o potencial dos movimentos em modificar as estruturas sociais, que teria sido superestimado na maioria dos estudos ao exaltarem o novo e desconsiderarem o papel das instituições dominantes. De acordo com esses críticos, os estudos seriam: "excessivamente otimistas quanto a seu impacto político, exaltando seu potencial para desafiar a ordem vigente de maneira autônoma, paradoxalmente ignorando o Estado e subestimando a importância dos partidos, o processo eleitoral e outras instituições" (BOSCHI,1987, p.15). O desempenho das mobilizações urbanas estaria circunscrito à ampliação dos direitos de cidadania, ao invés da transformação radical da sociedade e do sistema político (BOSCHI, ibid; JACOBI, 1988) ${ }^{17}$.

No cerne dessa avaliação crítica dos impactos dos movimentos no sistema político residia a pressuposição do caráter cíclico dos movimentos sociais, que seria incompatível com a sua aspiração a mecanismo de mudança social. A vida cíclica dos movimentos é explicada pelos autores nos seguintes termos:

Os movimentos sociais atravessam, todos eles, um ciclo de vida. Tal ciclo vai desde os antecedentes da mobilização, passando

16 O debate em torno da controvérsia "autonomia versus institucionalização" é analisado em Paoli (1995), Doimo (1995) e Machado e Ribeiro (1985).

${ }^{17}$ Telles (1994) e Dagnino (1994) também analisaram o papel dos movimentos sociais na ampliação dos direitos de cidadania. Mas, a partir de enfoque diametralmente oposto daqueles autores, abordando não a realização objetiva do direito reivindicado, mas o seu significado político-cultural para a sociedade, mediante a emergência e generalização de uma nova noção de direitos e de nova cidadania, embebida na concepção de "direito a ter direitos". 
pela criação de oportunidades de atuação coletiva, até à própria constituição do movimento, o qual ou pode se desdobrar em outros processos associativos ou se rotinizar e ainda perecer. (BOSCHI; VALLADARES, 1983, p.136)

A fase cíclica inicial é identificada às ações de mobilização e protesto público, com grande participação em modalidades variadas de atividades coletivas, seguida por momentos ou estágios que, hipoteticamente, tendem à desmobilização, à complexificação organizacional, à profissionalização e à institucionalização do movimento social, das quais derivam suas possibilidades de durabilidade e extensão no tempo (BOSCHI; VALLADARES, ibid.). Nas palavras de Jacobi (1988, p.300-301), "os movimentos representam um ciclo de vida bastante preciso, passando por estágios de maior e menor mobilização, mas configurando um processo onde a consecução das metas imediatas representa, geralmente, o fim da mobilização”. Essa abordagem de circuito cíclico de fluxos e refluxos na ação coletiva, desconsiderando a heterogeneidade das estratégias de atuação dos atores e dos níveis de participação, contrapõe uma natureza supostamente volátil dos movimentos sociais à dimensão temporal da institucionalização, da qual resultariam os maiores êxitos em termos de realização dos objetivos coletivos. A institucionalização é vista como um estágio no processo de constituição de sujeitos coletivos e inerente à lógica da ação coletiva (BOSCHI, 1987), em consonância com a teoria do processo político (PP) de complexificação organizacional e de profissionalização da ação coletiva.

Enquanto os estudiosos dos novos movimentos sociais viam no caráter autônomo das ações diretas sua possibilidade de pressão e influência no aparelho do Estado, os teóricos inspirados na centralidade do Estado e das instituições, por um lado, circunscreveram a autonomia dos atores coletivos à sua esfera discursiva, dissociando-a de sua práxis política cotidiana e, por outro lado, fixaram no estágio institucionalizado as chances efetivas de influência na correlação de forças com os governos. Renato Boschi assim relata a existência de uma contradição insolúvel entre autonomia e institucionalização:

Constatei [nas associações de moradores] a presença de um impulso autonomista e inovador na rejeição das formas tradicionais de atuação política e na criação de alternativas ao nível das próprias coletividades. (...) Mas a práxis política exigia dessas coletividades o enfrentamento cotidiano com o Estado e, para 
tanto, mais do que as demonstrações ou a participação errática das massas, tornava-se essencial algum mecanismo institucional que assegurasse autonomia e eficácia na representação de interesses. E precisamente aquele meio-termo parecia difícil atingir, já que a manutenção da autonomia levava a um provável insucesso, enquanto um êxito relativo caracterizava o envolvimento pela lógica do Estado. (BOSCHI, 1987, p.14)

Na verdade, a instauração dessa dicotomia analítica entre autonomia e institucionalização não faz sentido e a oposição supostamente intransponível entre ambas as dimensões da ação coletiva obstruiu avanços na análise da relação sociedade-Estado. Nesse aspecto, ambos os enfoques teóricos tenderam a antever manipulação, cooptação e dependência nas interações das coletividades com o aparato estatal, conferindo autonomia e independência às ações diretas ou de protesto público, comumente vistas como desenvolvidas nos contextos de restrição democrática e de não acesso às instituições políticas. Nos termos de Machado e Ribeiro (1985, p.326), nesse caso, "todo o esforço analítico fica canalizado e limitado por uma polarização que antecipa as conclusões: de um lado, cooptação e/ou esvaziamento; de outro, mobilização e/ou enfrentamento".

Entende-se que as dimensões da autonomia e da institucionalização dos movimentos não devem ser definidas a priori como estágios de um processo, correlacionadas a modalidades prefixadas e dicotômicas de estratégias de ação (protesto público versus ação institucionalizada) e de relações entre sociedade e Estado (conflito versus integração). Isso, pois, os movimentos sociais possuem a habilidade de desenvolver modos múltiplos, complementares e híbridos de ação, podendo, muitos deles, combinar uma estrutura organizacional complexa com um discurso de autonomia do Estado em um contexto predominantemente de protesto público. O inverso também é verdadeiro, quero dizer, alguns movimentos institucionalmente inseridos e engajados em órgãos governamentais podem manter um discurso ressignificado de autonomia dos poderes constituídos, não definido por distanciamento ou "não relação" com estes, mas auto percebido pelos atores nas interações com a institucionalidade política. O fato é que existem muita variedade e gradações nos sentidos de autonomia e também nos de institucionalização dos sujeitos coletivos e, naturalmente, toda tentativa de monocromatizar essas matizes ou encaixá-las em estágios evolutivos é infecunda e empobrecedora da complexidade social. 
A perspectiva cíclica e evolutiva da relação entre os movimentos e o Estado, ao conceber as mobilizações coletivas como desempenhando tão somente um papel conjuntural, com impactos transitórios e parciais sobre o Estado, enfoca a análise no padrão de ação institucionalizado e na sua transmutação em estruturas de representação de interesses perduráveis. A durabilidade e continuidade temporal do movimento, nesse sentido, dependeriam de sua integração às estruturas institucionais do Estado, mediante sua transformação em partidos políticos, em grupos de interesse ou, nos termos de Jacobi (1988), em alguma modalidade de "enquadramento institucional"18. Esses autores, se avançam na recuperação da dimensão institucional da ação coletiva, incorrem, ao mesmo tempo, num certo "reducionismo" ao esquecerem que o conflito político não se esgota no plano institucional. Ademais, predomina nessa abordagem a visão de Estado e de instituições políticas como ambiente externo aos atores coletivos, que os impede de conceber a esfera institucional como um campo político que é continuamente construído em interação com sujeitos societários, mediante processos reciprocamente constitutivos.

Entende-se que a continuidade do movimento ao longo do tempo pode assumir diferentes contornos, assim como a ideia de institucionalização pode admitir distintos significados. O contexto de inserção institucional em arranjos participativos de elaboração de políticas públicas, por exemplo, multiplicados no Brasil pós 1990, propiciou novas oportunidades de participação e representação de movimentos sociais na esfera governamental, possibilitando sua atuação em um continuum. Tais movimentos, institucionalmente inseridos, desenvolvem processos de complexificação organizacional e de cooperação com o Estado, ao mesmo tempo em que nutrem a participação dos militantes no processo decisório. Além disso, esses movimentos podem desenvolver, circunstancialmente, interações conflitivas e autônomas com o campo governamental. A institucionalização do canal de mediação sociedadeEstado através das instituições participativas de políticas públicas representa uma particularidade, cuja diversidade dos padrões de interação socioestatais acende a possibilidade de superação do suposto dilema autonomia versus institucionalização, com os atores societários exercendo criticamente sua atuação nas agências governamentais.

18 Para uma perspectiva similar a essa ver também Azevedo e Prates (1991). 
Ascontrovérsiase polêmicasentreosenfoquesanalíticosforamalimentadas, igualmente, pela visão de Estado da abordagem extrainstitucional e de autonomia dos movimentos. Em interlocução crítica com essa perspectiva predominante no país, Ruth Cardoso (1983) ponderou que o paradigma não institucional dos movimentos, sua visão de negação do Estado e de autonomia das coletividades, desconsiderou a análise específica das funções do Estado e de suas substantivas transformações, enaltecendo somente o seu caráter autoritário, opressivo e manipulador em contraposição a uma sociedade civil democrática e libertária. Nas palavras da autora:

O personagem 'Estado' entrou neste novo cenário com uma caracterização um pouco pobre, definido apenas como inimigo autoritário ou a mira contra o qual se movia a sociedade civil. Esta, sim, foi descrita como diversificada, conflitiva, dinâmica e espontânea, enquanto a mudança nos métodos de trabalho de alguns setores governamentais ficou esquecida. (CARDOSO, 1983, p.321).

Em outros termos, o Estado foi descrito como figura monolítica e relativamente opaca, contrastado a uma sociedade civil espontânea, inovadora em suas práticas, independente das elites políticas e dos partidos e unificada contra a opressão e a manipulação, cujo modelo analítico reproduzia uma visão dicotômica em torno da oposição movimento social versus sistema político-institucional. Nessa análise, reside uma noção polarizada de processo político que fraciona movimento e instituições, quer dizer, "o processo político é o conflito entre estes dois campos, cujo resultado não é concebido como uma síntese que transforma ambos, mas como a diluição de um pela interferência vitoriosa do outro" (MACHADO; RIBEIRO, 1985, p.327).

$\mathrm{Na}$ perspectiva analítica voltada para um "sentimento 'oposicionistademocrático' das massas urbanas e [que] deixa na sombra a atuação do Estado", o caráter ambíguo do aparelho estatal e seu papel transformador se nublam (CARDOSO, ibid., p. 319). Baseada no estudo de Carlos Nelson Ferreira dos Santos (1981), entre outros, que aponta deslocamentos no papel dos órgãos governamentais, a autora sublinha em novas formas de gestão ou administrações mais modernas e eficientes o diálogo e a negociação entre agentes governamentais e a população beneficiária de serviços públicos. Tencionando aquelas afirmações de negatividade indiscriminada da institucionalidade política, os autores defendem que as ações diretas de cunho reivindicativo, ao dirigirem seus clamores ao aparato do Estado, 
produzem um espaço peculiar de debate com os governos, pressionandoos a algum tipo de interação e requerendo a sua esfera provedora de bens de consumo coletivo. Essa parece ter sido a sugestão de Ruth Cardoso, ao afirmar que a sociedade organizada em movimentos não somente luta pelo seu reconhecimento como ator político legítimo e de seus direitos de cidadania, mas atua em prol da realização prática de suas demandas e carências, realizando, para tanto, negociações contínuas com órgãos do governo.

Os movimentos sociais representariam, nesse sentido, uma dupla face a expressiva e a reivindicativa. Mediante sua face expressiva os movimentos denunciam, simbolicamente, a exclusão das camadas populares e clamam seus direitos de cidadãos e, através da face reivindicativa almejam, pragmaticamente, objetivos em políticas governamentais (CARDOSO, 1983). Essa dupla face dos movimentos em sua relação com o Estado foi posteriormente desenvolvida por Ana Doimo (1995), que a colocou em termos de uma sociabilidade cambiante:

Seus atores tendem a desenvolver uma sociabilidade cambiante por entre os termos da sua dupla face: a expressivo-disruptiva, pela qual se manifestam valores morais ou apelos ético-políticos, tendentes a deslegitimar a autoridade pública e a estabelecer fronteiras intergrupos; e a integrativo-corporativa, pela qual buscam conquistar maiores níveis de integração social pelo acesso a bens e serviços, não sem disputas intergrupos e a interpelação direta dos oponentes (DOIMO, 1995, p.222, grifo no original).

As contribuições da autora são substantivas, valorizando dimensões tanto culturais quanto institucionais da ação coletiva, no geral, por reconhecer que os movimentos, ao mesmo tempo em que elaboram referências de autonomia do Estado e de democracia de base, conformando códigos éticopolíticos inscritos em valores e significados que orientam e dão sentido à ação dos atores, desenvolvem padrões de convivência positiva com a institucionalidade, mediante reivindicação à face provedora do Estado.

Contudo, o seu pressuposto de correlação entre interação movimentoEstado e contexto político, por um lado, e estratégia de ação, por outro, requer alguns apontamentos. Segundo a autora, as duas modalidades de relação movimento-Estado seriam fenômenos conjunturais decorrentes do maior ou menor acesso dos atores coletivos ao sistema político: os contextos políticos de transição ou regimes fechados ao processamento de demandas 
tenderiam a exacerbar a face expressivo-disruptiva dos movimentos, ao passo que, nas conjunturas mais democráticas e permeáveis às demandas coletivas os atores manifestariam sua face integrativo-corporativa.

Essa correlação entre tipo de interação movimento-Estado e contexto de ação corresponde a um "determinismo político" que impede desnudar a variação e a contingência na manifestação da ação coletiva. Ao contrário dessa perspectiva, entende-se que as modalidades de interação, por ora, "expressiva" ou "integrativa" podem se manifestar em diferentes contextos políticos, tanto os autoritários quanto os democráticos. Nesse sentido, embora o contexto político seja variável importante, o mesmo não é determinante das interações do movimento com o Estado, com o qual concorrem outros elementos explicativos. De fato, os movimentos podem desenvolver habilidades de combinarem variados padrões de relação com a institucionalidade política, seja nos contextos autoritários ou democráticos, e articularem, circunstancialmente, sua face "expressiva" e "integrativa" em cada uma das conjunturas políticas.

Por sua vez, permanece certo dualismo na conexão estabelecida pela autora entre padrões de interação e estratégia de ação, na medida em que o "lado expressivo" é remetido às atividades disruptivas e protestos mobilizatórios e o "lado integrativo-reivindicativo" aos diálogos e negociações corporativas, correlacionando-as, diametralmente, às estratégias, ora não institucionalizada ora institucionalizada. Assim, ao estabelecer relações com o Estado, seja em prol da expressão dos seus valores, identidades e direitos de cidadania, seja voltado aos interesses mais pragmáticos ou instrumentais, o movimento pode fazê-lo combinando uma variedade de formas de ação que compreende desde as estratégias contenciosas e disruptivas até as ações institucionalizadas de encaminhamento de demandas e solicitação de apoios aos partidos políticos e políticos aliados. Desse modo, mesmo que cada contexto histórico tenha sua estratégia predominante de ação, os militantes podem direcionar suas reivindicações e proposições ao poder público fazendo uso de canais múltiplos e complementares e combinar, de modo contingente, estratégias de contestação e de integração. ${ }^{19}$ De acordo com Abers, Serafim e Tatagiba (2011) a variedade de formas de participação de movimentos sociais e de

19 Evidências empíricas de movimentos sociais que combinam o uso de estratégias institucionalizadas e disruptivas para encaminhar demandas ao poder público podem ser encontradas em Carlos (2012), Dowbor (2012) e Tatagiba (2010). 
relação com o Estado compreende um "repertório de interação", no qual inclui-se um conjunto de rotinas: participação institucional, lobby, protesto, política de proximidade ou de relação direta e ocupação de cargos públicos. Tais repertórios de interação "envolvem muito mais do que experiências formais de participação institucionalizada: incluem também outras práticas de diálogo e conflito entre Estado e movimentos sociais que são utilizadas em combinação com a participação em arenas formalmente instituídas" (ABERS; SERAFIM; TATAGIBA, ibid., p.24-25).

Nas interações com o Estado e suas instituições, os movimentos sociais além de combinarem estratégias de ação diversificadas as utilizam em função de seus objetivos múltiplos. Os movimentos, assim, não protestam somente o reconhecimento de suas identidades e tampouco negociam apenas a ação provedora do Estado, mas utilizam ambos os elementos do que seria sua dupla face - expressiva e integrativa - para o conjunto de suas intencionalidades, tanto no plano cultural quanto material. Nesses termos, o estabelecimento de padrões de negociação com a esfera governamental compreende tanto a face expressiva-cultural do movimento, quanto seu lado integrativoreivindicativo. Em complemento, os movimentos não somente se integram às estruturas do Estado, mas, ao fazê-lo, podem desenvolver interações cooperativas e de colaboração mútua com a esfera governamental, assim como relações conflitivas e contestatórias.

É nesse sentido que o aprofundamento acerca da diversidade das modalidades de ação coletiva e interações socioestatais pode favorecer a compreensão mais ampla do movimento, em suas diferenciações tanto interna quanto externa, mitigando processos de homogeneização analítica que tendem a subordinar as diferenças e gradações a uma avaliação quase constante do significado político das coletividades.

Argumenta-se que a valorização da compreensão dos movimentos em sua heterogeneidade carece do reconhecimento conjunto de suas dimensões cultural-simbólica e político-institucional, engrendradas nas interações entre os atores societários e estatais. Alguns autores no país, ao revelarem a falácia das análises dicotômicas e polarizadas para a compreensão da complexidade dos movimentos, apontam a necessidade da integração das abordagens analíticas e de interpretação do processo político como um todo, no sentido de intercambiarem ambos os polos - movimento e sistema institucional numa mesma análise. Também em perspectiva conciliatória, endossa-se a afirmação de Durham acerca da insuficiência de cada um dos enfoques - a interpretação a partir "de dentro" do movimento e a visão "de fora" e "para 
fora" - e a proposta da autora de combinação dos enfoques para análise adequada dos movimentos, superando, de um lado, "a restrição de uma interpretação que, esmiuçando internamente o objeto, não vê sua inserção no processo mais amplo do qual faz parte" e, de outro, "as limitações de uma visão apriorística da história” (DURHAM, 1984, p.24).

Essa abordagem de conciliação e complementaridade entre as abordagens analíticas também marcou o debate internacional, como analisado anteriormente. Muitos estudiosos ponderaram que a variedade de formas, orientações e modos de ação dentro e entre os movimentos contemporâneos indica que os mesmos não devem ser concebidos como atores unificados e coerentes. Nesse sentido, parece mais útil assumir a ambiguidade e o "hibridismo" como características dos atores coletivos e os seus elementos, frequentemente polarizados nos paradigmas, como coexistentes dentro dos movimentos - algumas vezes em harmonia, mas geralmente em conflito. Isso significa dizer que os movimentos sociais ocupam-se com a produção simbólica e a construção de identidades, ao mesmo tempo em que dirigem suas demandas para o Estado; que eles combinam ação expressiva e instrumental e operam simultaneamente no nível cultural e político-institucional; que eles enfatizam sua autonomia dos atores políticos tradicionais, mas não operam em isolamento das instituições e, circunstancialmente, fazem alianças com atores institucionais (CANEL, 1992; OFFE, 1985; MUNCK, 1997; entre outros).

No entanto, esses apelos não resultaram em uma síntese teórica entre os paradigmas de ação coletiva que considerasse a complexidade e diversidade na constituição dos movimentos - no plano cultural e no institucional, no âmbito expressivo e no estratégico-instrumental. Por outro lado, é preciso reconhecer que os estudos no país acerca das relações dos movimentos com os chamados "agentes externos" (setores da Igreja, partidos políticos, sindicatos, agências governamentais, dentre outros ${ }^{20}$ foram fundamentais ao propósito de integração das abordagens, na medida em que alguns partiram dos significados culturais dos movimentos e buscaram compreender sua interação com institucionalidades diversas e, outros, debruçaram sobre a relação com

\footnotetext{
${ }^{20}$ Para uma análise das relações do movimento com a Igreja, ver Doimo (1984 e 1995), Krischke (1987) e Sader (1988); com o Estado, agentes governamentais e partidos políticos, ver Boschi (1983 e 1987), Jacobi (1983 e 1988) e Sader (ibid.); e com assessores de apoio, ver Landim (1995).
} 
os agentes políticos e a natureza dos mecanismos de poder presentes na constituição da ação coletiva ${ }^{21}$. Não obstante os significativos avanços nesse campo de estudos, tendo o mesmo focalizado o papel da configuração das instituições e dos governos na constituição das práticas políticas dos atores coletivos, a separação analítica entre as esferas da sociedade civil e do Estado os impediu de atentar para o fato de que as interações entre atores societários e institucionais compreende um processo dinâmico de coconstituição e de influência mútua que condiciona a ação dos sujeitos de ambos os domínios.

Em suma, defende-se o reconhecimento concomitante da dimensão cultural e institucional das práticas coletivas e de sua inter-relação com as configurações do Estado, como esferas que interagem e se determinam mutuamente, cujos processos de interação afetam os atores societários e estatais.

\section{Considerações finais: movimentos sociais, sistema político e sua mútua constituição}

Os movimentos sociais se constituem no contexto das relações entre a sociedade civil e o Estado. O reconhecimento das interações e imbricações entre os atores societários e as estruturas diversas é imprescindível à adequada compreensão da complexidade e diversidade dos movimentos. Nesse sentido, a classificação estanque e dicotômica das esferas da sociedade e do Estado, comum às teorias dos movimentos sociais em voga, precisa ser refutada e substituída por uma visão que considere a dimensão coconstitutiva e mutuamente influente de ambos os domínios, conforme argumentado. Especialmente em contextos democráticos de engajamento de atores coletivos na esfera governamental é fundamental considerar que as fronteiras entre os movimentos e o sistema político são imprecisas e fluidas e que os atores de ambos os campos se entrecruzam e engajam em atividades que os conectam mediante relações que são mutuamente influentes. A concepção de independência entre as esferas societárias e institucionais,

\footnotetext{
${ }^{21}$ Os esforços de estudiosos brasileiros em integrar cultura e política na análise dos movimentos sociais da década de 1980 são examinados em Ribeiro (1991).
} 
como blocos unitários e opostos, ao contrário, impede a consideração adequada das interações e interconectividades que impactam as práticas e os significados das ações estabelecidas entre tais esferas, assim como obstrui o desenvolvimento de uma linguagem para explicar esses processos dinâmicos de interação e suas implicações sobre os diversos atores.

É nesse sentido que a compreensão dos movimentos sociais em sua relação com o sistema político é favorecida pela perspectiva que enfatiza a variabilidade que caracteriza ambos os campos e sua configuração como decorrente de um processo interativo de mútua constituição e, portanto, recusa as abordagens estritamente centradas no Estado ou na sociedade como esferas separadas e autônomas, cuja relação é concebida como antagônica ou conflito de soma zero. ${ }^{22}$ Essa abordagem, por considerar os atores estatais e societários como politicamente significativos, interpreta o modo pelo qual os mesmos interagem e se constituem reciprocamente, conforme explicam os analistas:

A recíproca constituição entre "Estado" e "sociedade", ou entre instituições políticas e atores societários ocorre mediante processos que, ao longo do tempo e no mesmo movimento, vão moldando e sendo moldados pelas diferentes instituições políticas existentes (GURZA LAVALLE; HOUTZAGER; CASTELLO, 2011, p.209).

Sob esse enfoque teórico, atores estatais e societários, cujas capacidades são condicionadas pelas possibilidades de arquitetar o "encaixe institucional", desenvolvem habilidades de ação mediante processos reiterados de interação em torno da produção de políticas (HOUTZAGER, 2004; GURZA LAVALLE; HOUTZAGER; CASTELLO, ibid.). A capacidade de encaixe (ou fit) de atores societários e estatais "depende das oportunidades relativas que instituições políticas existentes oferecem para grupos ou movimentos", ao mesmo tempo em que as restringe a outros, enquanto pontos de acesso às instituições e de influência política no processo de decisão (SCKOPOL, 1992, p.54). A porosidade e permeabilidade do Estado e das instituições aos segmentos organizados da sociedade são evidenciadas pela existência de múltiplos pontos de acesso no legislativo, no executivo e nas agências

\footnotetext{
${ }^{22}$ Esta abordagem de Estado-sociedade aqui defendida é originária de trabalhos de Skocpol, 1992; Evans, 1995; Migdal, Kohli e Shue, 1994; Somers, 1993.
} 
estatais mediante os quais atores institucionalmente inseridos influenciam o processo político.

A institucionalidade política, ao mesmo tempo que possibilita as oportunidades de acesso e influência de atores hábeis para projetar seu encaixe institucional, cria-lhes constrangimentos, dado seus efeitos de organização. Em outras palavras, as instituições "influenciam quais grupos sociais se agregam a atores coletivos, como estes atores se organizam e que tipos de alianças constroem" (HOUTZAGER, 2004, p.33). Ao enfocar a relação entre atores estatais e societários, essa abordagem nutriu estudos relevantes acerca do papel crítico que o Estado e as instituições políticas desempenham na constituição da sociedade civil, por um lado, possibilitando oportunidades de acesso e influência política e, por outro, constrangendo a habilidade de atores políticos de arquitetar o encaixe institucional (SKOCPOL, 1992; HOUTZAGER, ibid.).

Contudo, o reconhecimento amplo do postulado de coconstituição entre Estado e sociedade civil exige que a ênfase na centralidade da configuração institucional dos governos e dos sistemas de partidos, como condicionante crucial da ação de atores políticos e sociais, seja complementada pela noção de que "o condicionamento, além de recíproco, é de índole iterativa e molda tanto as capacidades dos atores societários quanto as das instituições políticas", conforme intuído por Gurza Lavalle, Houtzager e Castello (2011, p.218). É nos termos de uma consideração mais equilibrada de ambas as capacidades do Estado e da variedade de forças sociais na formação das políticas, que Kohli e Shue (1994) também enfatizam as interações entre esses domínios como mutuamente condicionadas e transformadoras ${ }^{23}$.

A articulação do pressuposto de coconstituição entre sociedade civil e Estado às teorias dos movimentos sociais nos permite considerar os atores societários e institucionais como politicamente relevantes e mutuamente imbricados na conformação da ação coletiva e das interações socioestatais.

\footnotetext{
${ }^{23}$ Ver ainda: Somers (1993) e Baiocchi (2005) que compreendem a sociedade civil e o Estado como um sistema de interação mutuamente constituído e impactado.
} 


\section{Referência}

ABERS, Rebecca; SERAFIM, Lizandra; TATAGIBA, Luciana.

(2011). A participação na era Lula: repertórios de interação em um Estado heterogêno. Anais do $35^{\circ}$ Encontro Anual da Associação Nacional de Pós-graduação em Ciências Sociais (ANPOCS). Minas Gerais, Caxambu.

ALEXANDER, Jeffrey.

(1998). Ação coletiva, cultura e sociedade civil. Secularização, atualização, inversão, revisão e deslocamento do modelo clássico dos movimentos sociais. Revista Brasileira de Ciências Sociais, vol. 13, n. 37, p.114-145.

ALONSO, Angela.

(2009). As teorias dos movimentos sociais: um balanço do debate. Lua Nova - Revista de cultura e política, n.76, p.49-86.

ALVAREZ, Sonia; DAGNIN0, Evelina; ESCOBAR, Arturo.

(2000). 0 cultural e o político nos movimentos sociais latino-americanos. In: Sonia Alvarez; Evelina Dagnino; Arturo Escobar (Orgs.); Cultura e política nos movimentos sociais latino-americanos. Novas leituras. Belo Horizonte: Ed. UFMG. p. 15-60.

AZEVED0, Sérgio; PRATES, Antonio Augusto Pereira.

(1991). Planejamento participativo, movimentos sociais e ação coletiva. Ciências Sociais Hoje. São Paulo: Vértice/Anpocs. p.122-152.

BAIOCCHI, Gianpaolo.

(2005). Militants and Citizens. The politics of participatory democracy in Porto Alegre. California: Stanford University Press.

BOSCHI, Renato (Org.).

(1987). A arte da associação. Política de base e democracia no Brasil. São Paulo/Rio de Janeiro: Vértice/Iuperj.

(1983). Movimentos coletivos no Brasil urbano. Rio de Janeiro: Zahar.
BOSCHI, Renato; VALLADARES, Lícia do Prado.

(1983). Movimentos associativos de camadas populares urbanas: análise comparativa de seis casos. In: Renato Boschi (Org.); Movimentos coletivos no Brasil urbano. Rio de Janeiro: Zahar. p.103-143.

BUECHLER, Steven.

(1995). New Social Movement Theories. The Sociological Quarterly, vol. 36, n. 3, p.441464.

CALHOUN, Craig.

(1993). New social movements" of the Early Nineteenth Century. Social Science History; Vol. 17, n. 3, p.385-427.

CANEL, Eduardo.

(1992). New social movement theory and resource mobilization theory: the need for integration. In: CARROLL, William. (Ed.); Organizing dissent: contemporary social movements in theory and practice. Toronto: Garamond. p.22-51.

CARDOSO, Ruth.

(1987). Movimentos sociais na América Latina. Revista Brasileira de Ciências Sociais, vol. 1, n. 3, p.27-37.

(1983). Movimentos sociais urbanos: balanço crítico. In: Bernardo Sorj; Maria Hermínia Tavares Almeida (Orgs.); Sociedade política no Brasil pós-64. São Paulo: Brasiliense.

CARLOS, Euzeneia.

(2012). Movimentos sociais e instituições participativas: efeitos organizacionais, relacionais e discursivos. Tese de Doutorado de Programa de Pós-graduação em Ciência Política da Faculdade de Filosofia, Letras e Ciências Humanas, da Universidade de São Paulo.

CASTELLS, Manuel.

(1976). Lutas urbanas e poder político. Portugal, Porto. 
COHEN, John.

(1985). Strategy or Identity: New Theoretical Paradigms and Contemporary Social Movements. Social Research, vol. 52, n. 4, p.663-716.

COHEN, John.; ARATO, Andrew.

(1992). Los movimientos sociales y la sociedad civil. In: John Cohen; Andrew Arato. Sociedad civil y teoria política. México: Fundo de Cultura Econômica, p.556-635.

DAGNIN0, Evelina.

(2000). Cultura, cidadania e democracia: a transformação dos discursos e práticas na esquerda latino-americana. In: Sonia Alvarez; Evelina Dagnino; Arturo Escobar. Cultura política nos movimento sociais latinoamericanos. Minas Gerais: Ed. UFMG. p. 61101.

(1994). Os movimentos sociais e a emergência de uma nova noção de cidadania. In: Evelina Dagnino (Org.). Anos 90: política e sociedade no Brasil. São Paulo: Brasiliense, p. 103-115.

DALTON, Russell; KULCHLER, Monfred (Orgs.). (1990). Challenging the political order: new social and political movements in Western democracies. Cambridge: Polity Press.

DELLA PORTA, Donatella.; DIANI, Mario.

(2006). Social Movements: an introduction. $2^{\circ}$ Ed. Blackwell.

D0IM0, Ana.

(1995). A vez e a voz do popular: movimentos sociais e participação política no Brasil pós70. Rio de Janeiro: Relume-Dumaré/Anpocs.

(1984). Movimento social urbano, igreja e participação popular: movimento de transporte coletivo de Vila Velha, Espírito Santo. Petrópolis: Vozes, 116p.

D00W0N, Suh.

(2006). Civilsocietyin politicaldemocratization: social movement impacts and institutional politics. Development and Society, vol. 35, n. 2, p. 173-195.
DOWBOR, Monika.

(2012). Aarte da institucionalização: estratégias de mobilização dos sanitaristas (1974-2006). Tese de Doutorado apresentada Programa Pósgraduação da Ciência Política da Faculdade de Filosofia, Letras e Ciências Humanas, da Universidade de São Paulo.

DURHAM, Eunice Ribeiro.

(1984). Movimentos sociais: a construção da cidadania. Novos Estudos, n. 10, p.24-30.

EVERS, Tilman.

(1984). Identidade: a face oculta dos movimentos sociais. Novos Estudos, vol. 2, n. 4, p.11-23.

GAMSON, William.

(1990). The strategy of social protest. $2^{\mathrm{a}}$ Ed.. Belmont, California: Wadsworth.

GIUGNI, Marco; PASSY, Florence.

(1998). Contentious politics in complex societies: new social movements between conflict and cooperation. In: Marco Giugi; Doug McAdam; Charles Tilly (Eds.); From contention to democracy. Rowman and Littlefield Publishers. p.81-107.

GOHN, Maria da Glória.

(2002). Teorias dos movimentos sociais. Paradigmas clássicos e contemporâneos. $3^{\mathrm{a}}$ Ed. São Paulo: Loyola.

(1988). Luta pela moradia popular em São Paulo: movimentos de moradia - 1975/85. Ciências Sociais Hoje, p. 311-333.

(1982). Reivindicações populares urbanas. São Paulo: Cortez.

GOLDSTONE, Jack.

(2004). More Social Movements or Fewer? Beyond Political Opportunity Structures to Relational Fields. Theory and Society, vol. 33, n. 3/4, p.333-365.

(2003). Bridging institucionalized and noninstitucionalized politics. In: Jack Goldstone (Ed.); States, parties, and social movements. Cambridge: CambridgeUniversity Press. p.1-24. 
GURZA LAVALLE, Adrian; HOUTZAGER, Peter; CASTELLO, Graziela.

(2011). La construcción política de las sociedades civiles. In: Adrian Gurza Lavale (Org.); El horizonte de la política. Brasil y la agenda contemporánea de investigación en el debate internacional. México: CIESAS. p.207267.

HANAGAN, Michael.

(1998). Social movements, incorporation, disengagement, and opportunities - a long view. In: Marco Giugni; Doug McAdam; Charles Tilly (Eds.); From contention to democracy. Rowman and Littlefield Publishers. p.3-29.

HOUTZAGER, Peter.

(2004). Os últimos cidadãos. Conflito e Modernização no Brasil Rural. São Paulo: Globo.

JACOBI, Pedro.

(1988). Movimentos sociais e Estado: efeitos político-institucionais da ação política. Ciências Sociais Hoje. São Paulo: Vértice/ Anpocs, p. 290-310.

(1987). Movimentos sociais: teoria e prática em questão. In: Ilse Scherer-Warren; Paulo Krischke; Revolução no cotidiano? 0s novos movimentos sociais na América do Sul. São Paulo: Brasiliense. p.246-275.

(1983). Movimentos populares urbanos e resposta do Estado: autonomia e controle vs. cooptação e clientelismo. In: Renato Bochi (Org.); Movimentos coletivos no Brasil urbano. Rio de Janeiro: Zahar, p.145-179.

KOHLI, Atul; SHUE, Vivienne.

(1994). State power and social forces: on political contention and accomodation in the Third World. In: Joel Samuel Migdal; Atul Khol; Vivienne Shue. State Power and Social Forces: Dominations and Transformation in the Third World. Cambridge, Cambridge University Press. p.293-326.

KOWARICK, Lucio. (Org.).

(1988). As lutas sociais e a cidade. Rio de Janeiro: Paz e Terra.
(1987). Movimentos urbanos no Brasil contemporâneo: uma análise da literatura. Revista Brasileira de Ciências Sociais. São Paulo, n. 3, vol. 1, p.38-50.

KRIESI, Hans Peter.

(1999). La estructura organizacional de los nuevos movimientos sociales en su contexto político. In: Doug McAdam; John McCarthy; Mayer Zald (Eds.); Movimientos sociales: perspectivas comparadas. Madrid: Istmo. p.221-261.

KRISCHKE, Paulo.

(1987). Movimentos sociais e transição política: contribuições da democracia de base. In: Ilse Warren-Scherer; Paulo Krischke. Revolução no cotidiano? 0s novos movimentos sociais na América do Sul. São Paulo: Brasiliense. p.276-297.

LANDIM, Leilah.

(1995). Notas para um Perfil das ONGs - As Pertencentes à Associação Brasileira de ONGs. Rio de Janeiro, ISER.

MACHADO DA SILVA, Luís Antônio; RIBEIR0, Ana Clara Torres.

(1985). Paradigma e movimento social: por onde andam nossas idéias. Ciências Sociais Hoje, São Paulo: Vértice/Anpocs, n. 2, p.318336.

McADAM, Doug.

(1982). Political process and the development of Black Insurgency, 1930-1970. Chicago: University of Chicago Press.

MCADAM, Doug.; TARROW, Sidney.; TILLY, Charles.

(2001). Dynamics of contention. Cambridge studies in contentious politics. Cambridge: CambridgeUniversity Press.

McADAM, Doug; McCARTHY, John; ZALD, Mayer Zald (Eds.).

(1999). Movimientos sociales: perspectivas comparadas. Madrid: Istmo.

McCARTHY, John.; ZALD, Mayer.

(1973). The trends of social movements in America: professionalization and resource 
mobilization. Morristown, N. J.: General Learning Press.

(1977). Resource mobilization and social movements: a partial theory. The American Journal of Sociology, vol. 82, n. 6, p.12121241.

MELUCCI, Alberto.

(2002). Acción colectiva, vida cotidiana y democracia. México: El Colegio de México, Centros de Estudios Sociológicos.

(1996). Challenging codes. Cambridge/New York: CambridgeUniversity Press.

(1989). Nomads of the present. London: Hutchinson Radius.

(1985). The symbolic challenge of contemporary movements. Social Research, vol. 52, n. 4, p.789-816.

(1980). The new movements: a theoretical approach. Social Science Information, 19, 2, p.199-226.

MEYER, David; TARROW, Sidney.

(1998). A movement society: contentious politics for a new century. In: David Meyer; Sidney Tarrow (Orgs); The Social Movement Society: contentious politics for a new century. Lanham, Maryland and 0xford, England: Rowman \& Littlefield Publishers. p.1-28.

MICHELS, Robert.

(2001 [1962]). Para uma sociologia dos partidos políticos na democracia moderna. Lisboa: Antígona.

MIGDAL, Joel Samuel; KHOLI, Atul.; SHUE, Vivienne.

(1994). State Power and Social Forces: Dominations and Transformation in the Third World. Cambridge: Cambridge University Press.

MISCHE, Ann.

(2008). Partisan Publics: communication and contention across Brazilian youth activist networks. Princeton, NJ: PrincetonUniversity Press.
(2003). Cross-talk in movements: reconsceiving the culture-network link. In: Mario Diani; Doug McAdam (Orgs.); Social movements and networks. Relational approaches to collective action. 0xford University Press.

MOISÉS, José Álvaro.

(1992). Contradições urbanas, Estado e movimentos sociais. In: José Álvaro Moisés et al. (Org.); Cidade, povo e poder. Rio de Janeiro: Paz e Terra / CEDEC.

MOUFFE, Chantal.

(1988). Hegemony and new political subjects: toward a new concept of democracy. In: Carl Nelson; Laurence Grossberg (Ed.); Marxism and the interpretation of culture. Chicago: University of Illinois Press.

MUNCK, Gerardo.

(1997). Formação de atores, coordenação social e estratégia política: problemas conceituais do estudo dos movimentos sociais. Dados, vol. 40, n. 1.

\section{OFFE, Class.}

(1985). New social movements: challenging the boundaries of institutional politics. Social Research, vol. 52, n. 4, p.817-868.

PAOLI, Maria Célia.

(1995). Movimentos sociais no Brasil: em busca de um estatuto político. In: Michaela Hellmann (Org.); Movimentos sociais e democracia no Brasil. "Sem a gente não tem jeito". São Paulo: Marco Zero/Ildesfes/Labor. p.24-55.

PIVEN, Frances Fox; CLOWARD, Richard.

(1979). Poor people's movements: why they succeed and how they fail. New York: Vintage Books.

RASCHKE, Joachim.

(1994). Sobre el concepto de movimiento social. Zona Abierta, n. 69, p.121-134.

RIBEIR0, Ana Clara Torres.

(1991). Movimentos sociais: caminhos para a defesa de uma temática ou os desafios dos anos 90. Ciências Sociais Hoje. São Paulo: Vértice / Anpocs, p.95-121. 
SADER, Eder.

(1988). Quando novos personagens entram em cena. Experiências, falas e lutas dos trabalhadores da Grande São Paulo (197080). São Paulo: Paz e Terra.

SANTOS, Carlos Nelson Ferreira.

(1981). Movimentos urbanos no Rio de Janeiro. Rio de Janeiro: Zahar.

SZWAK0, José Eduardo León.

(2012). 'Del otro lado de la vereda': luta feminista e construção democrática no Paraguai pós-ditatorial. Tese de doutorado apresentada ao Instituto de Filosofia e Ciências Humanas da Universidade Estadual de Campinas (Unicamp).

SINGER, Paul.

(1981). Movimentos sociais em São Paulo: traços comuns e perspectivas. In: Paul Singer; Vinícius Caldeira Brant (Orgs.); São Paulo: o povo em movimento. $2^{a}$ Ed., Petrópolis/São Paulo: Vozes/Cebrap. p.207-231.

SKOCPOL, Theda.

(1992). Protecting Soldiers and Mothers: The Political Origins of Social Policy in the United States. Cambridge: Belknap Press/Harvard University Press.

SOMERS, Margaret.

(1993). Citizenship and the place of the public sphere: law, community, and political culture in the transition to democracy. American Sociology Review, 58, p.587-620.

TARROW, Sidney.

(2009 [1998]). 0 poder em movimento. Movimentos sociais e confronto político. Petrópolis/RJ: Vozes.

(1997). Elpoderen movimiento. Los movimientos sociales, la acción colectiva y la política. Madri: Alianza Editorial.

TATAGIBA, Luciana.

(2010). Desafios da relação entre movimentos sociais e instituições políticas. 0 caso do movimento de moradia da cidade de São Paulo - Primeiras reflexões. Colombia Internacional, 71, p.63-83.
TELLES, Vera.

(1987). Movimentos sociais: reflexões sobre a experiência dos anos 70. In: Ilse Schrerwarren; As lutas sociais e a cidade. São Paulo: passado e presente. São Paulo: Paz e Terra / Cedec / UNRISD. p. 247-283.

SCHERER-WARREN, Ilse; KRISCHKE, Paulo.

(1987). Revolução no cotidiano? Os novos movimentos sociais na América do Sul. São Paulo: Brasiliense. p.54-85.

(1994). Sociedade civil e a construção de espaços públicos. In: Evelina Dagnino (Org.); Anos 90: política e sociedade no Brasil. São Paulo: Brasiliense. p.91-102.

TILLY, Charles.

(1978). From mobilization to revolucion. Newberry Award Records.

TONI, Fabiano.

(2001). Novos rumos e possibilidades para os estudos de movimentos sociais. BIB - Revista Brasileira de Informação Bibliográfica em Ciências Sociais, n. 52, p.79-104.

TOURAINE, Alain.

(1988). Return to the actor. Minneapolis, University of Minnesota Press.

(1985). An introduction to the study of social movements. Social Research, 52, p. 749-788.

VON BÜLOW, Marisa; ABERS, Rebecca.

(2011). Movimentos sociais na teoria e na prática: como estudar o ativismo através da fronteira entre Estado e sociedade?. Sociologias, ano 13, n. 28, p.52-84.

\section{Recebido em}

março de 2014

Aprovado em

agosto de 2014 